\title{
Securinega Alkaloids from Flueggea leucopyra
}

\author{
Guo-cai WAnG, ${ }^{a, b}$ Ying WANG, ${ }^{a, b}$ Xiao-qi ZhANG, ${ }^{a, b}$ Yao-lan LI ${ }^{a, b}$ Xin-sheng YAO, ${ }^{a, b}$ and \\ Wen-cai YE*,a,b \\ ${ }^{a}$ Institute of Traditional Chinese Medicine and Natural Products, Jinan University; and ${ }^{b}$ Guangdong Province Key \\ Laboratory of Pharmacodynamic Constituents of TCM and New Drugs Research, Jinan University; Guangzhou 510632, \\ P. R. China. Received November 21, 2009; accepted December 21, 2009; published online December 24, 2009
}

Six new Securinega alkaloids $(1,3,5,7,9,10)$ together with four known ones were isolated from the twigs and leaves of Flueggea leucopyra. The structures of new compounds were established on the basis of the spectroscopic methods including UV, IR, HR-electrospray ionization (ESI)-MS, 1D and 2D NMR, and the absolute configurations of these new alkaloids were assigned by the modified Mosher's method and the circular dichroism (CD) spectra.

Key words Flueggea leucopyra; Euphorbiaceae; Securinega alkaloid; absolute configuration

The Securinega alkaloids are a group of polycyclic compounds isolated from the plants of Securinega and Phyllanthus genera (Euphorbiaceae). ${ }^{1}$ Previous phytochemical investigations had led to the isolation of a number of Securinega alkaloids, ${ }^{1-8)}$ which exhibited antimalarial, anti-

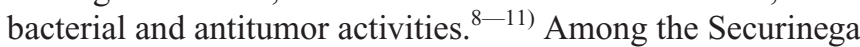
alkaloids, securinine was a major alkaloid obtained from the plant Securinega suffruticosa ${ }^{12)}$ and clinically applied to treat sequela of poliomyelitis and aplastic anemia. ${ }^{13)}$ Pharmacology investigations indicated that securinine was a stereospecific $\mathrm{GABA}_{\mathrm{A}}$ receptor antagonist with a significant central nervous system (CNS) activity. ${ }^{14,15)}$ In searching for bioactive alkaloids from the Euphorbiaceae plants, we had isolated some chemical constituents from Securinega suffruticosa and Flueggea virosa., ${ }^{3,4)}$ Flueggea leucopyra was a shrub which only distributed in Sichuan and Yunnan Provinces of China. Recently, our phytochemical study of $F$. leucopyra had resulted in the isolation of six new Securinega alkaloids together with four known ones (Fig. 1). This paper reports the isolation and structural elucidation of the new alkaloids $(\mathbf{1}, \mathbf{3}, \mathbf{5}, \mathbf{7}, \mathbf{9}, \mathbf{1 0})$ from the twigs and leaves of $F$. leucopyra.

\section{Results and Discussion}

The air-dried twigs and leaves of $F$. leucopyra were extracted with $95 \% \mathrm{EtOH}$. The solution was evaporated in vacuum to get a residue. The residue was suspended in $\mathrm{H}_{2} \mathrm{O}$ and then adjusted to $\mathrm{pH} 6$ with $5 \% \mathrm{HCl}$. The acidic suspension was partitioned with $\mathrm{CHCl}_{3}$ to remove the neutral component. The aqueous layer was basified with $\mathrm{NH}_{3} \cdot \mathrm{H}_{2} \mathrm{O}$ and extracted with $\mathrm{CHCl}_{3}$ to obtain a residue. Repeated column chromatography of the residue afforded six new compounds $(1,3,5,7,9,10)$ and four known compounds $(2,4,6,8)$. The known compounds were identified by comparison with the
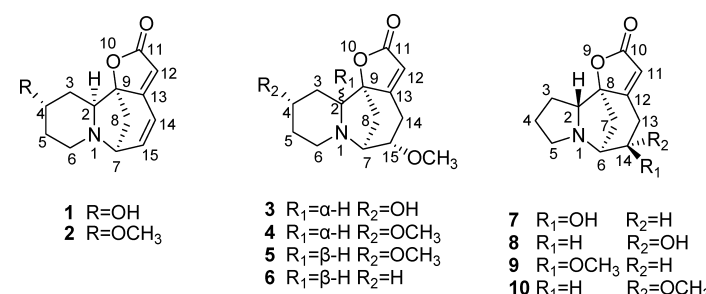

Fig. 1. Chemical Structures of Compounds $\mathbf{1}-\mathbf{1 0}$ literature data as securitinine (2), ${ }^{5)}$ secu'amamine B (4), ${ }^{8)}$ secu'amamine $\mathrm{C}(\mathbf{6}),{ }^{8)}$ and fluggeainol $(\mathbf{8}),{ }^{6,7)}$ respectively.

1 was obtained as yellow oil, and its molecular formula was determined as $\mathrm{C}_{13} \mathrm{H}_{15} \mathrm{NO}_{3}$ on the basis of HR-electrospray ionization (ESI)-MS at $\mathrm{m} / \mathrm{z}$ : $234.1127[\mathrm{M}+\mathrm{H}]^{+}$(Calcd for $\left.\mathrm{C}_{13} \mathrm{H}_{16} \mathrm{NO}_{3}, 234.1125\right)$. The IR spectrum of 1 implied the presence of hydroxyl group $\left(3436 \mathrm{~cm}^{-1}\right)$ and $\alpha, \beta$-unsaturated $\gamma$-lactone ring $\left(1746,1632 \mathrm{~cm}^{-1}\right)$. An $\alpha, \beta$-unsaturated $\gamma$-lactone ring at $\delta_{\mathrm{C}} 174.0,168.8,110.7$ and 92.9 , a double bond at $\delta_{\mathrm{C}} 124.3$ and 150.1, and an oxygenated methine at $\delta_{\mathrm{C}} 64.9$ were observed in the ${ }^{13} \mathrm{C}$-NMR spectrum. Accordingly, the ${ }^{1} \mathrm{H}-\mathrm{NMR}$ spectrum showed three olefinic protons at $\delta_{\mathrm{H}} 5.71$ $(1 \mathrm{H}, \mathrm{br} \mathrm{s}), 6.64(1 \mathrm{H}, \mathrm{d}, J=9.2 \mathrm{~Hz})$ and $6.77(1 \mathrm{H}, \mathrm{dd}, J=9.2$, $5.2 \mathrm{~Hz}$ ), and an oxygenated proton at $\delta_{\mathrm{H}} 4.19(1 \mathrm{H}, \mathrm{m})$ (Table 1). All the data indicated that $\mathbf{1}$ was a securinine type alkaloid with a hydroxyl group. ${ }^{5)}$

Comparison of ${ }^{1} \mathrm{H}$ - and ${ }^{13} \mathrm{C}-\mathrm{NMR}$ data of $\mathbf{1}$ (Table 1) with those of securitinine ${ }^{5)}(2)$ revealed that the signals of the two compounds were very similar, except the absence of the methoxyl group in $\mathbf{1}$ as well as the upfield shift of C-4 from $\delta_{\mathrm{C}} 72.8$ in $\mathbf{2}$ to $\delta_{\mathrm{C}} 64.9$ in $\mathbf{1}$, suggesting that $\mathbf{1}$ had a hydroxyl group at $\mathrm{C}-4$ position. This was further confirmed by the heteronuclear multiple bond connectivity $(\mathrm{HMBC})$ correlations between $\mathrm{H}-4\left(\delta_{\mathrm{H}} 4.19\right)$ and $\mathrm{C}-2\left(\delta_{\mathrm{C}} 57.0\right)$ and C-6 $\left(\delta_{\mathrm{C}}\right.$ 43.7) (Fig. 2). The relative configuration of 1 was assigned as shown in Fig. 3 by the nuclear Overhauser effect spectroscopy (NOESY) correlations between $\mathrm{H}-2$ and H-6a, between $\mathrm{H}-4$ and H-6b, as well as between H-2 and H-8a. The circular dichroism (CD) spectrum of $\mathbf{1}$ showed Cotton effects at $\lambda_{\max } 216 \mathrm{~nm}(\Delta \varepsilon-3.34)$ and $312 \mathrm{~nm}(\Delta \varepsilon-17.37)$, which were similar to those of securitinine (2) $\left[\lambda_{\max } 227 \mathrm{~nm}(\Delta \varepsilon\right.$ $-1.13)$ and $302 \mathrm{~nm}(\Delta \varepsilon-19.36)]$. Furthermore, the absolute configuration of 1 was confirmed by application of the modified Mosher's method. ${ }^{16)}$ Differences of proton chemical shift ( $\Delta \delta$ values, $\delta_{S}-\delta_{R}$ ) between $(S)$ - $\alpha$-methoxy- $\alpha$-(trifluoromethyl)phenylacetic acid (MTPA) ester (1a) and (R)-MTPA ester (1b) (Fig. 4) indicated the presence of $S$ configuration at C-4 in $\mathbf{1}$. Hence, the absolute configuration of $\mathbf{1}$ was assigned as $2 S, 4 S, 7 S$, and $9 S$. 1 was identified as $4 \alpha$-hydroxyallosecurinine.

3 was isolated as yellow oil, and its HR-ESI-MS showed an $[\mathrm{M}+\mathrm{H}]^{+}$ion peak at $m / z$ : 266.1387 (Calcd for $\mathrm{C}_{14} \mathrm{H}_{20} \mathrm{NO}_{4}$, 266.1387) for the molecular formula of $\mathrm{C}_{14} \mathrm{H}_{19} \mathrm{NO}_{4}$. The presence of $\alpha, \beta$-unsaturated $\gamma$-lactone ring 
Table 1. NMR Data of $\mathbf{1}, \mathbf{3}$ and $\mathbf{5}\left(\mathrm{CDCl}_{3}, J\right.$ in $\left.\mathrm{Hz}\right)$

\begin{tabular}{|c|c|c|c|c|c|c|}
\hline \multirow{2}{*}{ Position } & \multicolumn{2}{|r|}{1} & \multicolumn{2}{|c|}{3} & \multicolumn{2}{|r|}{5} \\
\hline & $\delta_{\mathrm{C}}$ & $\delta_{\mathrm{H}}$ & $\delta_{\mathrm{C}}$ & $\delta_{\mathrm{H}}$ & $\delta_{\mathrm{C}}$ & $\delta_{\mathrm{H}}$ \\
\hline 2 & 57.0 & $3.95(\mathrm{dd}, 12.8,4.0)$ & 61.5 & $3.51^{a)}$ & 60.2 & $2.96^{a)}$ \\
\hline \multirow[t]{2}{*}{3} & 32.5 & $1.39^{a}$ & 34.0 & $1.62^{a)}$ & 33.8 & $2.14(\mathrm{~m})$ \\
\hline & & $1.35^{a)}$ & & $1.06(\mathrm{~m})$ & & $1.28^{a)}$ \\
\hline 4 & 64.9 & $4.19(\mathrm{~m})$ & 66.0 & $4.14(\mathrm{t}, 2.8)$ & 77.4 & $3.23^{a)}$ \\
\hline \multirow[t]{2}{*}{5} & 34.4 & $2.18(\mathrm{~m})$ & 35.5 & $1.69^{a)}$ & 32.1 & $1.80(\mathrm{~m})$ \\
\hline & & $1.53(\mathrm{~m})$ & & $1.61^{a)}$ & & $1.27^{a)}$ \\
\hline \multirow[t]{2}{*}{6} & 43.7 & $2.78(\mathrm{~m})$ & 47.5 & $3.04(\mathrm{~m})$ & 48.9 & $3.06^{a)}$ \\
\hline & & $2.56(\mathrm{~m})$ & & $2.79^{a)}$ & & $2.95^{a)}$ \\
\hline 7 & 60.1 & 3.89 (brt, 4.8$)$ & 60.1 & $3.35(\mathrm{brt}, 5.2)$ & 62.9 & $3.33^{a)}$ \\
\hline \multirow[t]{2}{*}{8} & 44.1 & $2.67(\mathrm{dd}, 10.0,4.0)$ & 36.2 & $2.34(\mathrm{dd}, 10.8,4.6)$ & 33.6 & $2.51(\mathrm{dd}, 11.2,4.8)$ \\
\hline & & $1.91(\mathrm{~d}, 10.0)$ & & $1.99(\mathrm{~d}, 10.8)$ & & $1.90(\mathrm{~d}, 11.2)$ \\
\hline 9 & 92.9 & - & 91.0 & - & 92.3 & - \\
\hline 11 & 174.0 & - & 174.1 & - & 174.6 & - \\
\hline 12 & 110.7 & $5.71(\mathrm{brs})$ & 114.6 & $5.68(\mathrm{~d}, 2.4)$ & 112.6 & $5.64(\mathrm{brs})$ \\
\hline 13 & 168.8 & - & 172.2 & - & 174.1 & - \\
\hline \multirow[t]{2}{*}{14} & 124.3 & $6.64(\mathrm{~d}, 9.2)$ & 32.1 & $2.95(\mathrm{~m})$ & 30.6 & $2.84^{a)}$ \\
\hline & & - & & $2.74^{a)}$ & & $2.82^{a)}$ \\
\hline 15 & 150.1 & $6.77(\mathrm{dd}, 9.2,5.2)$ & 81.0 & $3.55^{a)}$ & 81.0 & $3.56(\mathrm{~d}, 2.8)$ \\
\hline $4-\mathrm{OCH}_{3}$ & & & & & 56.6 & $3.35(\mathrm{~s})$ \\
\hline $15-\mathrm{OCH}_{3}$ & & & 58.1 & $3.27(\mathrm{~s})$ & 58.2 & $3.30(\mathrm{~s})$ \\
\hline
\end{tabular}

a) Overlapped signals were reported without designating multiplicity.
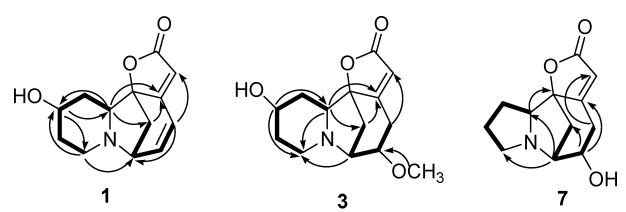

$\longrightarrow \underset{{ }_{H}-{ }^{-1} H \operatorname{COSY} Y}{\mathrm{MBC}}$

Fig. 2. Key HMBC and ${ }^{1} \mathrm{H}-{ }^{1} \mathrm{H}$ COSY Correlations of $\mathbf{1}, \mathbf{3}$ and 7
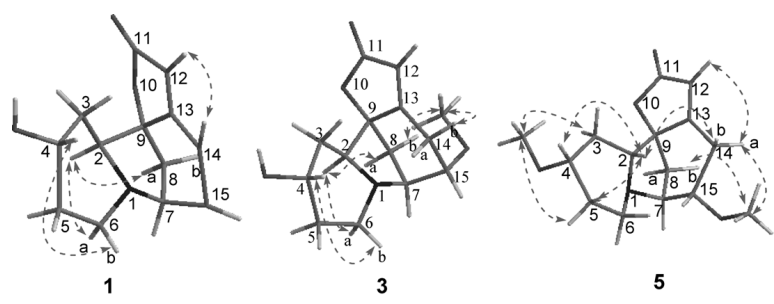

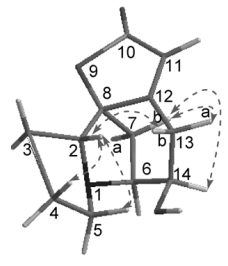

7

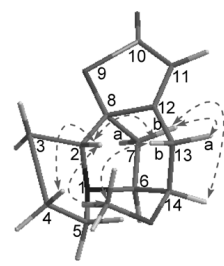

9

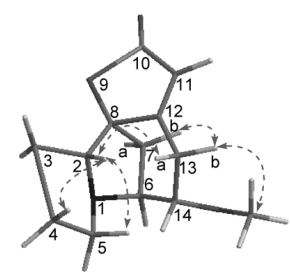

10
Fig. 3. Key NOESY Correlations of $\mathbf{1 , 3}, \mathbf{5}, \mathbf{7}, \mathbf{9}$ and $\mathbf{1 0}$

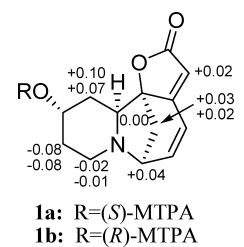

Fig. 4. $\Delta \delta$ Values $\left(\delta_{S}-\delta_{R}\right)$ of the MTPA Esters $\mathbf{1 a}$ and $\mathbf{1 b}$ was suggested by its IR spectrum $\left(1756,1643 \mathrm{~cm}^{-1}\right)$. Fourteen carbon signals including one methyl, five methylenes, five methines, and three quaternary carbons were showed by the ${ }^{13} \mathrm{C}$ and distortionless enhancement by polarization transfer (DEPT) NMR spectra. An $\alpha, \beta$-unsaturated $\gamma$-lactone ring $\left(\delta_{\mathrm{C}} 174.1,172.2,114.6,91.0\right)$, two oxygenated methines $\left(\delta_{\mathrm{C}}\right.$ $66.0,81.0)$ and a methoxyl group $\left(\delta_{\mathrm{C}} 58.1\right)$ were displayed in the ${ }^{13} \mathrm{C}$-NMR spectrum. In the ${ }^{1} \mathrm{H}$-NMR spectrum, an olefinic proton $\left(\delta_{\mathrm{H}} 5.68, \mathrm{~d}, J=2.4 \mathrm{~Hz}\right)$, two oxygenated protons $\left[\delta_{\mathrm{H}} 3.55(\mathrm{~m})\right.$ and $\left.4.14(\mathrm{t}, J=2.8 \mathrm{~Hz})\right]$ and a methoxy singlet $\left(\delta_{\mathrm{H}} 3.27, \mathrm{~s}\right)$ were observed. The above data indicated that 3 was a dihydrosecurinine type alkaloid with a methoxyl group and a hydroxyl group. ${ }^{8)}$

Comparison of NMR data of $\mathbf{3}$ (Table 1) with those of secu'amamine $\mathrm{B}^{8)}(4)$ showed that the NMR signals of the two compounds were similar, except that $\mathbf{3}$ only had a methoxyl group as well as the ${ }^{13} \mathrm{C}$-NMR value at $\mathrm{C}-4$ shifted from $\delta_{\mathrm{C}}$ 76.2 in 4 to $\delta_{\mathrm{C}} 66.0$ in $\mathbf{3}$, suggesting that 3 had a methoxyl group at $\mathrm{C}-15$ position and a hydroxyl group at $\mathrm{C}-4$ position. It was further confirmed by the $\mathrm{HMBC}$ correlations between $\mathrm{OCH}_{3}\left(\delta_{\mathrm{H}} 3.27\right)$ and $\mathrm{C}-15\left(\delta_{\mathrm{C}} 81.0\right)($ Fig. 2$)$. The NOESY correlations between $\mathrm{H}-2$ and $\mathrm{H}-6 \mathrm{a}$, between $\mathrm{H}-6 \mathrm{~b}$ and $\mathrm{H}-4$, between $\mathrm{H}-2$ and $\mathrm{H}-8 \mathrm{a}$, between $\mathrm{H}-8 \mathrm{~b}$ and $15-\mathrm{OMe}$, as well as between $15-\mathrm{OMe}$ and $\mathrm{H}-14 \mathrm{~b}$ (Fig. 3) established the relative configuration of 3 . The Cotton effects at $\lambda_{\max } 226 \mathrm{~nm}$ $(\Delta \varepsilon+2.87)$ and $277 \mathrm{~nm}(\Delta \varepsilon+0.76)$ in $\mathrm{CD}$ spectrum of $\mathbf{3}$ were similar to those of $4{ }^{8}{ }^{8}$ Therefore, the absolute configuration of 3 was assigned as $2 S, 4 S, 7 S, 9 S$, and $15 S$. The structure of 3 was elucidated as $4 \alpha$-hydroxy- $15 \alpha$-methoxy14,15-dihydroallosecurinine.

5 showed an $[\mathrm{M}+\mathrm{H}]^{+}$ion peak at $m / z$ : $280.1540(\mathrm{Calcd}$ for $\mathrm{C}_{15} \mathrm{H}_{22} \mathrm{NO}_{4}, 280.1543$ ) in the HR-ESI-MS spectrum, consistent with a molecular formula of $\mathrm{C}_{15} \mathrm{H}_{21} \mathrm{NO}_{4}$. The IR spectrum indicated the presence of $\alpha, \beta$-unsaturated $\gamma$-lactone ring $\left(1758,1644 \mathrm{~cm}^{-1}\right)$. The ${ }^{1} \mathrm{H}-$ and ${ }^{13} \mathrm{C}-\mathrm{NMR}$ data of $\mathbf{5}$ (Table 1) were very similar to those of secu'amamine B (4), suggesting that $\mathbf{5}$ was a dihydrosecurinine type alkaloid with 
Table 2. NMR Data of 7, 9 and $\mathbf{1 0}\left(\mathrm{CDCl}_{3}, J\right.$ in $\left.\mathrm{Hz}\right)$

\begin{tabular}{|c|c|c|c|c|c|c|}
\hline \multirow{2}{*}{ Position } & \multicolumn{2}{|r|}{7} & \multicolumn{2}{|r|}{9} & \multicolumn{2}{|r|}{10} \\
\hline & $\delta_{\mathrm{C}}$ & $\delta_{\mathrm{H}}$ & $\delta_{\mathrm{C}}$ & $\delta_{\mathrm{H}}$ & $\delta_{\mathrm{C}}$ & $\delta_{\mathrm{H}}$ \\
\hline 2 & 65.6 & $3.14^{a)}$ & 66.7 & $3.22^{a)}$ & 66.9 & $3.15(\mathrm{dd}, 8.8,6.4)$ \\
\hline \multirow[t]{2}{*}{3} & 28.9 & $1.89^{a)}$ & 29.1 & $1.91^{a)}$ & 30.3 & $1.90^{a)}$ \\
\hline & & $1.81^{a)}$ & & $1.75^{a)}$ & & $1.71^{a)}$ \\
\hline \multirow[t]{2}{*}{4} & 26.6 & $1.97^{a)}$ & 26.5 & $1.96^{a)}$ & 27.9 & $1.95^{a)}$ \\
\hline & & $1.79^{a)}$ & & $1.79^{a)}$ & & $1.71^{a)}$ \\
\hline \multirow[t]{2}{*}{5} & 57.2 & $3.36(\mathrm{~m})$ & 57.6 & $3.47(\mathrm{~m})$ & 58.6 & $3.36(\mathrm{~m})$ \\
\hline & & $2.63(\mathrm{~m})$ & & $2.62^{a)}$ & & $2.62(\mathrm{~m})$ \\
\hline 6 & 66.0 & $3.10^{a)}$ & 63.3 & $3.24^{a)}$ & 64.7 & $3.22(\mathrm{~m})$ \\
\hline \multirow[t]{2}{*}{7} & 29.5 & $2.33(\mathrm{dd}, 11.6,6.4)$ & 31.5 & $2.51(\mathrm{dd}, 11.6,6.4)$ & 31.2 & $2.27(\mathrm{dd}, 11.6,6.4)$ \\
\hline & & $1.96(\mathrm{~d}, 6.4)$ & & $1.31(\mathrm{~d}, 6.4)$ & & $1.81(\mathrm{~d}, 6.4)$ \\
\hline 8 & 91.8 & - & 91.4 & - & 92.5 & - \\
\hline 10 & 172.9 & - & 172.8 & - & 173.9 & - \\
\hline 11 & 111.1 & $5.66(\mathrm{~d}, 2.0)$ & 110.6 & $5.64(\mathrm{~d}, 2.4)$ & 112.3 & $5.59(\mathrm{~d}, 2.0)$ \\
\hline 12 & 172.9 & - & 171.5 & - & 173.9 & - \\
\hline \multirow[t]{2}{*}{13} & 32.2 & $2.93^{a)}$ & 29.4 & $3.22^{a)}$ & 30.1 & $2.88(\mathrm{~d}, 12.8)$ \\
\hline & & $2.80^{a)}$ & & $2.64^{a)}$ & & $2.77(\mathrm{~m})$ \\
\hline 14 & 69.1 & $4.24(\mathrm{t}, 4.4)$ & 79.8 & $3.34(\mathrm{dd}, 6.4,2.0)$ & 79.1 & $3.67(\mathrm{dd}, 4.8,4.4)$ \\
\hline $14-\mathrm{OCH}_{3}$ & & & 56.6 & $3.41(\mathrm{~s})$ & 58.1 & $3.26(\mathrm{~s})$ \\
\hline
\end{tabular}

a) Overlapped signals were reported without designating multiplicity.

two methoxyl groups. The HMBC spectrum showed the correlations between $\mathrm{OCH}_{3}\left(\delta_{\mathrm{H}} 3.35\right)$ and $\mathrm{C}-4\left(\delta_{\mathrm{C}} 77.4\right)$ as well as between $\mathrm{OCH}_{3}\left(\delta_{\mathrm{H}} 3.30\right)$ and $\mathrm{C}-15\left(\delta_{\mathrm{C}} 81.0\right)$, indicating that two methoxyl groups were located at $\mathrm{C}-4$ and $\mathrm{C}-15$ positions, respectively. The NOE correlation between $\mathrm{H}-2$ and $\mathrm{H}-$ $14 \mathrm{~b}$ (Fig. 3) indicated that the relative configuration at C-2 of 5 was opposite to those of $\mathbf{3}$ and $\mathbf{4}$. The absolute configuration of 5 was determined as $2 R, 4 S, 7 S, 9 S$, and $15 S$ by comparison of the CD spectrum of $\mathbf{5}$ with that of secu'amamine C (6). ${ }^{8)}$ Therefore, the structure of 5 was elucidated as $4 \alpha$ methoxy-15 $\alpha$-methoxy-14,15-dihydrosecurinine.

7 was obtained as yellow oil. The molecular formula of 7 was determined as $\mathrm{C}_{12} \mathrm{H}_{15} \mathrm{NO}_{3}$ according to the HR-ESI-MS at $m / z: 222.1126[\mathrm{M}+\mathrm{H}]^{+}$(Calcd for $\mathrm{C}_{12} \mathrm{H}_{16} \mathrm{NO}_{3}, 222.1125$ ). The IR spectrum showed the presence of hydroxyl group $\left(3442 \mathrm{~cm}^{-1}\right)$ and $\alpha, \beta$-unsaturated $\gamma$-lactone ring (1755, $\left.1631 \mathrm{~cm}^{-1}\right)$. The ${ }^{1} \mathrm{H}$-NMR spectrum showed an olefinic proton at $\delta_{\mathrm{H}} 5.66(\mathrm{~d}, J=2.0 \mathrm{~Hz})$ and an oxygenated proton at $\delta_{\mathrm{H}}$ 4.24 (t, $J=4.4 \mathrm{~Hz}$ ). The ${ }^{13} \mathrm{C}$-NMR spectrum displayed twelve carbon signals including five methylenes, four methines and three quaternary carbons. Furthermore, in the ${ }^{13} \mathrm{C}-\mathrm{NMR}$ spectrum, an $\alpha, \beta$-unsaturated $\gamma$-lactone ring at $\delta_{\mathrm{C}} 172.9$, $172.9,111.1$ and 91.8 as well as an oxygenated methine group at $\delta_{\mathrm{C}} 69.1$ were observed. The above data were very similar to those of fluggeainol $(8),{ }^{6,7)}$ indicating that 7 was a dihydronorsecurinine type alkaloid with a hydroxyl group. The position of hydroxyl group was assigned by the HMBC correlations between $\mathrm{H}-14\left(\delta_{\mathrm{H}} 4.24\right)$ and C-6 $\left(\delta_{\mathrm{C}} 66.0\right)$, C-7 $\left(\delta_{\mathrm{C}} 29.5\right)$ and C-12 $\left(\delta_{\mathrm{C}} 172.9\right)$ (Fig. 2$)$. The relative configuration of 7 was assigned by the NOE correlations between $\mathrm{H}$ 2 and $\mathrm{H}-13 \mathrm{~b}$, between $\mathrm{H}-7 \mathrm{~b}$ and $\mathrm{H}-13 \mathrm{a}$, as well as between $\mathrm{H}-7 \mathrm{~b}$ and H-14 (Fig. 3). The Cotton effects of $7\left[\lambda_{\max } 219 \mathrm{~nm}\right.$ $(\Delta \varepsilon-2.76), 238 \mathrm{~nm}(\Delta \varepsilon+1.74)$, and $265 \mathrm{~nm}(\Delta \varepsilon-0.85)]$ were also similar to those of fluggeainol $(\mathbf{8})\left[\lambda_{\max } 218 \mathrm{~nm}\right.$ $(\Delta \varepsilon-1.37), 231 \mathrm{~nm}(\Delta \varepsilon+2.67)$, and $261 \mathrm{~nm}(\Delta \varepsilon-0.27)]$. Hence, the absolute configuration of 7 was assigned as $2 R$, $6 S, 8 S$, and $14 R$. 7 was identified as $14 \beta$-hydroxy-13,14-dihydronorsecurinine.
9 was isolated as yellow oil. Its molecular formula was determined as $\mathrm{C}_{13} \mathrm{H}_{17} \mathrm{NO}_{3}$ by the HR-ESI-MS at $m / z$ : 236.1286 $[\mathrm{M}+\mathrm{H}]^{+}\left(\right.$Calcd for $\left.\mathrm{C}_{13} \mathrm{H}_{18} \mathrm{NO}_{3}, 236.1281\right)$. The IR spectrum of 9 implied the presence of $\alpha, \beta$-unsaturated $\gamma$-lactone ring $\left(1755,1649 \mathrm{~cm}^{-1}\right)$. Except for an additional methoxyl group $\left(\delta_{\mathrm{H}} 3.41 / \delta_{\mathrm{C}} 56.6\right)$, the ${ }^{1} \mathrm{H}-$ and ${ }^{13} \mathrm{C}-\mathrm{NMR}$ data of 9 were similar to those of 7 (Table 2), suggesting 9 was a dihydronorsecurinine type alkaloid with a methoxyl group. The HMBC correlations between $\mathrm{OCH}_{3}\left(\delta_{\mathrm{H}} 3.41\right)$ and C-14 $\left(\delta_{\mathrm{C}} 79.8\right)$ indicated that the methoxyl group was attached to $\mathrm{C}-14$ position. The relative configuration of 9 was assigned by NOESY correlations (Fig. 3). The CD spectrum $\left[\lambda_{\max } 208 \mathrm{~nm}(\Delta \varepsilon\right.$ $-2.56), 234 \mathrm{~nm}(\Delta \varepsilon+2.25)$, and $284 \mathrm{~nm}(\Delta \varepsilon-0.62)]$ of 9 was similar to those of $\mathbf{7}$ and $\mathbf{8}$, suggesting the absolute configuration of 9 was $2 R, 6 S, 8 S$, and $14 R$. Thus, the structure of 9 was elucidated as $14 \beta$-methoxy-13,14-dihydronorsecurinine.

10 was obtained as yellow oil. The molecular formula of 10 was established as $\mathrm{C}_{13} \mathrm{H}_{17} \mathrm{NO}_{3}$ by the HR-ESI-MS at $\mathrm{m} / \mathrm{z}$ : $258.1093[\mathrm{M}+\mathrm{Na}]^{+}$(Calcd for $\mathrm{C}_{13} \mathrm{H}_{17} \mathrm{NO}_{3} \mathrm{Na}, 258.1101$ ), which had the same molecular formular as 9. The IR spectrum showed the presence of $\alpha, \beta$-unsaturated $\gamma$-lactone ring $\left(1756,1642 \mathrm{~cm}^{-1}\right)$. The ${ }^{1} \mathrm{H}$ - and ${ }^{13} \mathrm{C}-\mathrm{NMR}$ spectra of $\mathbf{1 0}$ were also very similar to those of $\mathbf{9}$, suggesting that $\mathbf{1 0}$ was the isomeride of $\mathbf{9}$. In the NOESY spectrum of $\mathbf{1 0}$, the correlations between $\mathrm{H}-7 \mathrm{~b}$ and $\mathrm{H}-13 \mathrm{~b}$, as well as between $\mathrm{H}-13 \mathrm{~b}$ and $14-\mathrm{OMe}$ (Fig. 3) were observed, indicating that the configuration at C-14 of $\mathbf{1 0}$ was opposite to that of $\mathbf{9}$. The absolute configuration of $\mathbf{1 0}$ was finally determined as $2 R, 6 \mathrm{~S}$, $8 S$, and $14 S$ by comparing the CD spectrum of $\mathbf{1 0}$ with those of $7, \mathbf{8}$ and $\mathbf{9}$. Therefore, the structure of $\mathbf{1 0}$ was elucidated as $14 \alpha$-methoxy-13,14-dihydronorsecurinine.

\section{Experimental}

General Experimental Procedures Optical rotations were determined on a JASCO P-1020 polarimeter. UV spectra were obtained on a JASCO V$550 \mathrm{UV} / \mathrm{VIS}$ spectrophotometer. CD spectra were measured on a JASCO J720 spectrometer. IR spectra were obtained on a JASCO FT/IR-480 plus spectrometer. ${ }^{1} \mathrm{H}-,{ }^{13} \mathrm{C}$ - and 2D-NMR spectra were determined on a Bruker- 
$\mathrm{AV}-400$ spectrometer in $\mathrm{CDCl}_{3}$. ESI-MS spectra were run on a $\mathrm{HP}-1100$ HPLC/EST spectrometer. HR-ESI-MS spectra were obtained on a Biosystems Mariner ${ }^{\mathrm{TM}} 5140$ spectrometer. For column chromatography, silica gel (200 - 300 mesh, Qingdao Marine Chemical Factory, P. R. China), Sephadex LH-20 (Pharmacia) and ODS (YMC) were used. TLC analyses were carried out using precoated silica gel GF254 plates (Qingdao Marine Chemical Factory, P. R. China). HPLC separations were performed on a COSMOSIL $\mathrm{C}_{18}$ preparative column $(5 \mu \mathrm{m}, 20 \times 250 \mathrm{~mm})$.

Plant Material The twigs and leaves of F. leucopyra were collected in Nujiang country, Yunnan province of China, in September of 2006. The plant was authenticated by Prof. Guang-xiong Zhou of Jinan University. A voucher specimen (No. 060914) was deposited in the Institute of Traditional Chinese Medicine and Natural Products, Jinan University, Guangzhou, P. R. China.

Extraction and Isolation The air-dried twigs and leaves of F. leucopyra $(8.5 \mathrm{~kg})$ were extracted with $95 \% \mathrm{EtOH}$ and the solution was evaporated in vacuum to get a residue $(1045 \mathrm{~g})$. The residue was dissolved in $\mathrm{H}_{2} \mathrm{O}$ to form a suspension and then adjusted to $\mathrm{pH} 6$ with $5 \% \mathrm{HCl}$. The acidic suspension was partitioned with $\mathrm{CHCl}_{3}$ to remove the neutral components. The aqueous phase was basified with $2 \% \mathrm{NH}_{3} \cdot \mathrm{H}_{2} \mathrm{O}$ to $\mathrm{pH} 8$ and then extracted with $\mathrm{CHCl}_{3}$ to obtain a total alkaloid part $(42 \mathrm{~g})$, which was subjected to silica gel column chromatography $(\mathrm{CC})\left(\mathrm{CHCl}_{3}-\mathrm{CH}_{3} \mathrm{OH}, 100: 0 \rightarrow 0: 100\right)$ to give 10 fractions $(1-10)$. Fraction $3(3.86 \mathrm{~g})$ was subjected to silica gel CC (nhexane-EtOAc, $10: 1 \rightarrow 1: 1)$ to afford 8 subfractions (3-1-3-8). Subfraction 3-4 (346 mg) was purified by HPLC $\left[\mathrm{CH}_{3} \mathrm{OH}-\mathrm{H}_{2} \mathrm{O}-\left(\mathrm{CH}_{3} \mathrm{CH}_{2}\right)_{3} \mathrm{~N}\right.$, $85: 15: 0.02]$ to afford $\mathbf{8}(12 \mathrm{mg}), \mathbf{9}(11 \mathrm{mg})$ and $\mathbf{1 0}(9 \mathrm{mg})$. Fraction 4 $(2.76 \mathrm{~g})$ was purified by Sephadex LH-20 column $\left(\mathrm{CH}_{3} \mathrm{OH}\right)$ and silica gel $\mathrm{CC}\left(\mathrm{CHCl}_{3}-\mathrm{CH}_{3} \mathrm{OH}, 100: 0 \rightarrow 80: 20\right)$ to yield $4(21 \mathrm{mg})$ and $5(12 \mathrm{mg})$. Fraction $5(3.34 \mathrm{~g})$ was subjected to reversed-phase silica gel (ODS) CC $\left(\mathrm{CH}_{3} \mathrm{OH}-\mathrm{H}_{2} \mathrm{O}, 60: 40 \rightarrow 90: 10\right)$ to afford 9 subfractions $(5-1-5-9)$. Subfraction $5-3(569 \mathrm{mg})$ was purified by preparative HPLC $\left[\mathrm{CH}_{3} \mathrm{OH}-\mathrm{H}_{2} \mathrm{O}-\right.$ $\left.\left(\mathrm{CH}_{3} \mathrm{CH}_{2}\right)_{3} \mathrm{~N}, 70: 30: 0.02\right]$ to obtain $1(22 \mathrm{mg}), 3(19 \mathrm{mg})$ and $7(15 \mathrm{mg})$, respectively. Subfraction $5-4(369 \mathrm{mg})$ was purified by preparative HPLC $\left[\mathrm{CH}_{3} \mathrm{OH}-\mathrm{H}_{2} \mathrm{O}-\left(\mathrm{CH}_{3} \mathrm{CH}_{2}\right)_{3} \mathrm{~N}, \quad 75: 25: 0.02\right]$ to obtain $2(22 \mathrm{mg})$ and 6 (19 $\mathrm{mg})$, respectively.

$4 \alpha$-Hydroxyallosecurinine (1): Yellow oil; $[\alpha]_{\mathrm{D}}^{20}-102(c=0.07, \mathrm{MeOH})$; $\mathrm{UV}(\mathrm{MeOH}) \lambda_{\max }(\log \varepsilon) 218(1.65), 257(1.97) \mathrm{nm} ; \mathrm{CD}(\mathrm{MeOH}) \lambda_{\max }(\Delta \varepsilon)$ $216(-3.34), 312(-17.37) \mathrm{nm}$; IR (KBr) $v_{\max }: 3436,2948,1746,1632$, 1464, $1286 \mathrm{~cm}^{-1}$; ${ }^{1} \mathrm{H}$ - and ${ }^{13} \mathrm{C}-\mathrm{NMR}$ data see Table 1; ESI-MS $\mathrm{m} / \mathrm{z}: 234$ $[\mathrm{M}+\mathrm{H}]^{+}$; HR-ESI-MS $m / z: 234.1127[\mathrm{M}+\mathrm{H}]^{+}\left(\right.$Calcd for $\mathrm{C}_{13} \mathrm{H}_{16} \mathrm{NO}_{3}$, 234.1125).

$4 \alpha$-Hydroxy-15 $\alpha$-methoxy-14,15-dihydroallosecurinine (3): Yellow oil; $[\alpha]_{\mathrm{D}}^{20}-32(c=0.12, \mathrm{MeOH}) ; \mathrm{UV}(\mathrm{MeOH}) \lambda_{\max }(\log \varepsilon) 212(1.85) \mathrm{nm} ; \mathrm{CD}$ $(\mathrm{MeOH}) \lambda_{\max }(\Delta \varepsilon) 226(+2.87), 277(+0.76) \mathrm{nm} ; \mathrm{IR}(\mathrm{KBr}) v_{\max } 3447$, 2936, 1756, 1643,1438, $1268 \mathrm{~cm}^{-1}$; ${ }^{1} \mathrm{H}-$ and ${ }^{13} \mathrm{C}-\mathrm{NMR}$ data see Table 1; ESI-MS $m / z: 266[\mathrm{M}+\mathrm{H}]^{+}$; HR-ESI-MS $m / z: 266.1387[\mathrm{M}+\mathrm{H}]^{+}$(Calcd for $\mathrm{C}_{14} \mathrm{H}_{20} \mathrm{NO}_{4}, 266.1387$ ).

$4 \alpha$-Methoxy-15 $\alpha$-methoxy-14,15-dihydrosecurinine (5): Yellow oil; $[\alpha]_{\mathrm{D}}^{20}$ $+37(c=0.11, \mathrm{MeOH}) ; \mathrm{UV}(\mathrm{MeOH}) \lambda_{\max }(\log \varepsilon) 220$ (1.89) nm; CD $(\mathrm{MeOH}) \lambda_{\max }(\Delta \varepsilon) 218(-1.39), 240(+2.62), 279(+0.77), 334(-0.50)$ $\mathrm{nm}$; IR $(\mathrm{KBr}) v_{\max }: 3035,2928,1758,1644,1453,1204 \mathrm{~cm}^{-1} ;{ }^{1} \mathrm{H}-$ and ${ }^{13} \mathrm{C}-$ NMR data see Table 1; ESI-MS $m / z$ : $280[\mathrm{M}+\mathrm{H}]^{+}$; HR-ESI-MS $m / z$ : $280.1540[\mathrm{M}+\mathrm{H}]^{+}\left(\right.$Calcd for $\left.\mathrm{C}_{15} \mathrm{H}_{22} \mathrm{NO}_{4}, 280.1543\right)$.

$14 \beta$-Hydroxy-13,14-dihydronorsecurinine (7): Yellow oil; $[\alpha]_{\mathrm{D}}^{20}-45$ $(c=0.13, \mathrm{MeOH}) ; \mathrm{UV}(\mathrm{MeOH}) \lambda_{\max }(\log \varepsilon) 216(2.15) \mathrm{nm} ; \mathrm{CD}(\mathrm{MeOH})$ $\lambda_{\max }(\Delta \varepsilon) 219(-2.76), 238(+1.74), 265(-0.85) \mathrm{nm}$; IR $(\mathrm{KBr}) v_{\max }: 3442$, $2929,1755,1631,1460,1274 \mathrm{~cm}^{-1} ;{ }^{1} \mathrm{H}$ - and ${ }^{13} \mathrm{C}-\mathrm{NMR}$ see Table 2; ESI-MS $m / z: 222[\mathrm{M}+\mathrm{H}]^{+}$; HR-ESI-MS $m / z: 222.1126[\mathrm{M}+\mathrm{H}]^{+}$(Calcd for $\mathrm{C}_{12} \mathrm{H}_{16} \mathrm{NO}_{3}, 222.1125$ ).

14 $\beta$-Methoxy-13,14-dihydronorsecurinine (9): Yellow oil; $[\alpha]_{\mathrm{D}}^{20}-44$ $(c=0.16, \mathrm{MeOH}) ; \mathrm{UV}(\mathrm{MeOH}) \lambda_{\max }(\log \varepsilon) 216(2.21) \mathrm{nm} ; \mathrm{CD}(\mathrm{MeOH})$ $\lambda_{\max }(\Delta \varepsilon) 208(-2.56), 234(+2.25)$, and $284(-0.62) \mathrm{nm} ; \mathrm{IR}(\mathrm{KBr}) v_{\max }$ : $3135,2924,1755,1649,1451,1383 \mathrm{~cm}^{-1} ;{ }^{1} \mathrm{H}$ - and ${ }^{13} \mathrm{C}-\mathrm{NMR}$ data see Table 2; ESI-MS $m / z$ : $236[\mathrm{M}+\mathrm{H}]^{+}$; HR-ESI-MS $m / z: 236.1286[\mathrm{M}+\mathrm{H}]^{+}(\mathrm{Calcd}$ for $\mathrm{C}_{13} \mathrm{H}_{18} \mathrm{NO}_{3}, 236.1281$ ).

$14 \alpha$-Methoxy-13,14-dihydronorsecurinine (10): Yellow oil; $[\alpha]_{\mathrm{D}}^{20}+27$ $(c=0.10, \mathrm{MeOH}) ; \mathrm{UV}(\mathrm{MeOH}) \lambda_{\max }(\log \varepsilon) 217(2.05) \mathrm{nm} ; \mathrm{CD}(\mathrm{MeOH})$ $\lambda_{\max }(\Delta \varepsilon) 213(-1.71), 235(+2.69), 263(-1.75) \mathrm{nm} ; \mathrm{IR}(\mathrm{KBr}) v_{\max }: 2936$, $1756,1642,1460,1189 \mathrm{~cm}^{-1}$; ${ }^{1} \mathrm{H}-$ and ${ }^{13} \mathrm{C}-\mathrm{NMR}$ data, see Table 2; ESI-MS $m / z: 258[\mathrm{M}+\mathrm{Na}]^{+}$; HR-ESI-MS $m / z: 258.1093[\mathrm{M}+\mathrm{Na}]^{+}$(Calcd for

\section{$\left.\mathrm{C}_{13} \mathrm{H}_{17} \mathrm{NO}_{3} \mathrm{Na}, 258.1101\right)$}

Preparation of MTPA Esters of $1 \quad \mathbf{1}(4.5 \mathrm{mg})$ was dissolved in $0.5 \mathrm{ml}$ of dried pyridine and treated with $(R)-(-)-\alpha$-methoxy- $\alpha$-(trifluoromethyl) phenylacetyl chloride $(10 \mu \mathrm{l})$. The reaction product was stirred at room temperature overnight and then dried in vacuum. The reaction mixture was poured into water $(5 \mathrm{ml})$ and extracted with EtOAc $(5 \mathrm{ml})$. The EtOAc extract was purified by silica gel column chromatography [ $n$-hexane-EtOAc $(70: 30)]$ to yield $(S)$-MTPA ester (1a, $3.2 \mathrm{mg})$. (R)-MTPA ester (1), $2.7 \mathrm{mg})$ was obtained using the same method by treatment of $1(4.3 \mathrm{mg})$ with $(S)$ (+)- $\alpha$-methoxy- $\alpha$-(trifluoromethyl) phenylacetyl chloride.

(S)-MTPA Ester (1a): ${ }^{1} \mathrm{H}-\mathrm{NMR}\left(\mathrm{CDCl}_{3}, 400 \mathrm{MHz}\right) \delta: 1.63(1 \mathrm{H}, \mathrm{m}, \mathrm{H}-3 \mathrm{~b})$, $1.96(1 \mathrm{H}, \mathrm{d}, J=14.8 \mathrm{~Hz}, \mathrm{H}-3 \mathrm{~b}), 2.10(1 \mathrm{H}, \mathrm{m}, \mathrm{H}-5 \mathrm{~b}), 2.20(1 \mathrm{H}, \mathrm{d}, J=11.6 \mathrm{~Hz}$, $\mathrm{H}-8 \mathrm{~b}), 2.57$ (1H, dd, $J=16.0,9.6 \mathrm{~Hz}, \mathrm{H}-5 \mathrm{a}), 2.81(1 \mathrm{H}, \mathrm{dd}, J=14.0,12.8 \mathrm{~Hz}$, H-6b), 3.12 (1H, brd, $J=11.6 \mathrm{~Hz}, \mathrm{H}-8 \mathrm{a}), 3.55$ (1H, overlapped, H-6a), 3.60 (3H, s, OMe of MTPA), 4.12 (1H, dd, $J=14.0,3.2 \mathrm{~Hz}, \mathrm{H}-7), 4.81$ (1H, br s, $\mathrm{H}-2), 5.39(1 \mathrm{H}, \mathrm{m}, \mathrm{H}-4), 6.06(1 \mathrm{H}$, br s, H-12), $6.70(1 \mathrm{H}, \mathrm{dd}, J=8.8,6.4 \mathrm{~Hz}$, $\mathrm{H}-15), 7.01(1 \mathrm{H}, \mathrm{d}, J=8.8 \mathrm{~Hz}, \mathrm{H}-14), 7.27$ and 7.45 (phenyl protons of MTPA); ESI-MS $m / z: 450[\mathrm{M}+\mathrm{H}]^{+}$; HR-ESI-MS $m / z: 450.1519[\mathrm{M}+\mathrm{H}]^{+}$ (Calcd for $\mathrm{C}_{23} \mathrm{H}_{23} \mathrm{~F}_{3} \mathrm{NO}_{5}, 450.1523$ ).

(R)-MTPA Ester (1b): ${ }^{1} \mathrm{H}-\mathrm{NMR}\left(\mathrm{CDCl}_{3}, 400 \mathrm{MHz}\right) \delta: 1.56(1 \mathrm{H}, \mathrm{m}, \mathrm{H}-$ 3b), 1.86 (1H, dd, $J=14.8,2.0 \mathrm{~Hz}, \mathrm{H}-3 \mathrm{~b}), 2.18$ (1H, overlapped, H-5b), 2.18 $(1 \mathrm{H}, \mathrm{d}, J=11.6 \mathrm{~Hz}, \mathrm{H}-8 \mathrm{~b}), 2.65(1 \mathrm{H}, \mathrm{dd}, J=16.0,9.6 \mathrm{~Hz}, \mathrm{H}-5 \mathrm{a}), 2.82(1 \mathrm{H}$, dd, $J=14.0,12.8 \mathrm{~Hz}, \mathrm{H}-6 \mathrm{~b}), 3.09$ (1H, dd, $J=11.6,4.4 \mathrm{~Hz}, \mathrm{H}-8 \mathrm{a}), 3.57(1 \mathrm{H}$, overlapped, H-6a), 3.60 (3H, s, OMe of MTPA), $4.08(1 \mathrm{H}, \mathrm{dd}, J=14.0$, $3.6 \mathrm{~Hz}, \mathrm{H}-7), 4.81$ (1H, t, $J=4.8 \mathrm{~Hz}, \mathrm{H}-2), 5.35$ (1H, m, H-4), 6.04 (1H, br s, $\mathrm{H}-12), 6.70(1 \mathrm{H}, \mathrm{dd}, J=8.8,6.4 \mathrm{~Hz}, \mathrm{H}-15), 7.01(1 \mathrm{H}, \mathrm{d}, J=9.0 \mathrm{~Hz}, \mathrm{H}-14)$, 7.27 and 7.45 (phenyl protons of MTPA). ESI-MS $m / z$ : $450[\mathrm{M}+\mathrm{H}]^{+}$; HRESI-MS $m / z$ : $450.1529[\mathrm{M}+\mathrm{H}]^{+}\left(\right.$Calcd for $\left.\mathrm{C}_{23} \mathrm{H}_{23} \mathrm{~F}_{3} \mathrm{NO}_{5}, 450.1523\right)$.

Acknowledgments This work was supported by grants from the Cheung Kong Scholars Program (to W. C. Y.), the National Science Fund for Distinguished Young Scholars (No. 30625039), the Joint Fund of NSFCGuangdong Province (No. U0932004), the National Natural Science Foundation of China (No. 20902038) and the China Postdoctoral Science Foundation (No. 20070410841).

\section{References}

1) Snieckus V., "The Alkaloids," Vol. 14, ed. by Manske R. H. F., Academic Press, New York, 1973, pp. 425-503.

2) Ohsaki A., Ishiyama H., Yoneda K., Kobayashi J., Tetrahedron Lett., 44, 3097-3099 (2003).

3) Wang Y., Li Q., Ye W.-C., Ip C.-F., Ip Y.-R., Zhao S.-X., Chin. Tradit. Herb Drugs, 38, 163-167 (2007).

4) Wang G.-C., Wang Y., Li Q., Liang J.-P., Zhang X.-Q., Yao X.-S., Ye W.-C., Helv. Chim. Acta, 91, 1124-1129 (2008).

5) Arbain D., Birkbeck A. A., Byrne L. T., Sargent M. V., Skelton B. W., White A. H., J. Chem. Soc. Perkin Trans. 1, 1991, 1863-1869 (1991).

6) Chen M. Q., Hou L. L., Acta Bot. Sin., 27, 625-629 (1985).

7) Dehmlow E. V., Guntenhoner M., Ree T. V., Phytochemistry, 52, 1715-1716 (1999)

8) Ohsaki A., Kobayashi Y., Yoneda K., Kishida A., Ishiyama H., J. Nat. Prod., 70, 2003-2005 (2007).

9) Weenen H., Nkunya M. H. H., Bray D. H., Mwasumbi L. B., Kinabo L. S., Kilimali V. A. E. B., Wijinberg J. P. B. A., Planta Med., 56, 371-373 (1990).

10) Mensah J. L., Lagarde I., Ceschin C., Michel G., Gleye J., Fouraste I., J. Ethnopharmacol., 28, 129-133 (1990).

11) Dong N. Z., Gu Z. L., Chou W. H., Kwok C. Y., Acta Pharm. Sin., 20, 267-270 (1999).

12) Saito S., Kotera K., Shigematsu N., Ide A., Sugimoto N., Horii Z., Hanaoka M., Yamawaki Y., Tamura Y., Tetrahedron, 19, 2085-2099 (1963).

13) Han G., LaPorte M. G., Folmer J. J., Werner K. M., Weinreb S. M., J. Org. Chem., 65, 6293-6306 (2000).

14) Rognan D., Boulanger T., Hoffmann R., Vercauteren D. P., Andre J. M., Durant F., Wermuth C. G., J. Med. Chem., 35, 1969-1977 (1992).

15) Galvez-Ruano E., Aprison M. H., Robertson D. H., Lapkowitz K. B., J. Neurosci. Res., 42, 666-673 (1995).

16) Ohtani I., Kusumi T., Kashman Y., Kakisawa H., J. Am. Chem. Soc., 113, 4092-4096 (1991). 